\title{
Influence of transverse rebars on bond between steel reinforcement and cellular concrete with very low compressive strength
}

\section{Influência do uso de barras transversais soldadas na aderência aço-concreto celular de baixíssima resistência à compressão}

P. R. N. SOUDAIS a pierre.engenharia@gmail.com

J. S. CAMACHO a jef@dec.feis.unesp.br

G. A. PARSEKIAN b parsekian@ufscar.br

\begin{abstract}
Cellular concrete is a lightweight concrete obtained by aerating agent, which produces air-voids into the mixture. This work deals with bond between cellular concrete and steel rebars. Pull-out tests of $4,2 \mathrm{~mm}$ diameter rebars partly immersed into concrete cylinders were made. Concrete unit weight variation and setting of a transverse rebar into the concrete cylinder center constitute the variables of the work. Three types of mixture were prepared: one without aerating agent (with a dry unit weight of $2255 \mathrm{~kg} / \mathrm{m}^{3}$ ), and two with different aerating agent rates (with a dry unit weight equal to 1565 and $1510 \mathrm{~kg} / \mathrm{m}^{3}$ ). The study revealed the large decrease of bond stress between 4,2 diameter rebars and cellular concrete, due to concrete unit weight reduction. Transverse rebar introduced into concrete cylinder center increased the ultimate pull-out force of the test: the gain of bond produced by the transverse rebar grew up when the cellular concrete unit weight had been reduced. Therefore, special anchorages (not exclusively straight), permitting bond improvement between cellular concrete and rebars could be a solution to improve the mechanical performance of cellular concrete.
\end{abstract}

Keywords: cellular concrete, bond stress, anchoring.

\section{Resumo}

O concreto celular, que se caracteriza por ter um peso próprio reduzido pela incorporação artificial de ar, pode constituir uma alternativa sustentável ao concreto comum nas estruturas de pequeno e médio porte. O presente trabalho trata da avaliação da aderência entre o concreto celular e as barras de aço. Foram realizados ensaios de arrancamento com barras de diâmetro igual a 4,2 mm, parcialmente imersas em corpos-de-prova cilíndricos de concreto. A taxa de agente espumígeno no concreto e a presença ou não de uma barra transversal dentro do cilindro, simulando uma condição mais próxima ao uso de tela de aço, constituem as variáveis da pesquisa. Foram utilizadas três dosagens de concreto, com massa específica aparente de 2255, 1565 e $1510 \mathrm{~kg} / \mathrm{m}^{3}$. Pelo arrancamento de barras simples de diâmetro igual a 4,2 mm, notou-se o forte decréscimo da tensão de aderência junto com o rebaixamento da massa específica aparente do concreto. A barra transversal permitiu obter um ganho de resistência ao arrancamento da barra longitudinal, que cresceu junto com o rebaixamento da massa específica do concreto celular. Assim, a utilização de ancoragens especiais (não exclusivamente retas), pode se tornar uma solução para melhorar o desempenho mecânico do concreto celular.

Palavras-chave: concreto celular, aderência, ancoragem.

Universidade Estadual Paulista "Júlio de Mesquita Filho" Faculdade de Engenharia, Departamento de Engenharia Civil, Ilha Solteira, SP. Brasil;

Universidade Federal de São Carlos, Departamento de Engenharia Civil, São Carlos, SP. Brasil.

Received: 26 Sep 2016 • Accepted: 11 Jan 2018 • Available Online:

This is an open-access article distributed under the terms of the Creative Commons Attribution License 


\section{Introduction}

In spite of his numerous advantages (e.g. good workability and high compressive strength), conventional reinforced concrete presents a high ratio between unit weight and mechanical strength. This disadvantage increases the structure weight and turns difficult the moving of precast elements. Another disadvantage is the fact that reinforced concrete conducts easily heat and sound, which requires the use of additional materials to insulate residential buildings (CARVALHO; FIGUEIREDO FILHO [1]). The reduction of concrete density permits to limit these disadvantages. According to ABNT NBR 8953:2015 [2], lightweight has a unit weight lower than $2000 \mathrm{~kg} / \mathrm{m}^{3}$. One way of reducing concrete unit weight is the insertion of air bubbles (ROSSIGNOLO [3]). The air bubble insertion into concrete affects the mechanical strength but increase thermal and acoustic insulation. So for buildings getting low loads and requiring a good thermal and acoustic insulation, lightweight concrete can be an alternative of conventional concrete and used as structural material. Reinforced concrete has a good mechanical behavior because concrete (resisting against compressive stresses) works jointly with steel reinforcement (resisting against tensile stresses). This solidarity is guaranteed by bond acting between the two materials and is equivalent to a stress transfer from steel to concrete (CARVALHO; FIGUEIREDO FILHO [1]). Thus a structural reinforced concrete element has to present as good bond conditions as possible. In this context, this paper reports a study of bond phenomenon (doing pull-out tests) between steel rebars and lightweight concrete (i.e. cellular concrete), in order to assess the structural use of this composite material.

\section{Literature review}

\subsection{Cellular concrete}

ABNT NBR 8953:2015 [2] defines three concrete categories in accordance with the 28 day unit weight: lightweight concrete $\left(\gamma_{28}<2000 \mathrm{~kg} / \mathrm{m}^{3}\right)$, conventional concrete $\left(2000 \mathrm{~kg} / \mathrm{m}^{3}<\gamma_{28}<2800\right.$ $\left.\mathrm{kg} / \mathrm{m}^{3}\right)$ and heavy concrete $\left(\gamma_{28}>2800 \mathrm{~kg} / \mathrm{m}^{3}\right)$. There are three types of lightweight concrete: with lightweight aggregates, without fine aggregates or cellular (ROSSIGNOLO [3]). Despite the fact that first attempts to develop cellular concrete dates from the beginning of the $20^{\text {th }}$ century (e.g. Eriksson in Sweden, considered as a forerunner in the field, patented one of his works in 1923), the dissemination of this material into the construction industry became significant only in the 1970s, after the advent of the organic chemistry (FERREIRA [4]). Concerning "aerated" cellular concrete, the porosity can be obtained by two ways. The first way, named "chemical aeration", consists of a reaction between a chemical product (e.g. powdered aluminum or hydrogen peroxide) and the rest of the mixture, creating gas before cement hydration of cement (TEIXEIRA FILHO; TEZUKA [5]). The second way consist in introducing a foaming agent into the mixture. There are two ways of introducing the foaming agent into the mixture. The first way consists in preparing the foaming agent with a specific machine and in adding it into the concrete mixture ("pre-formed foam"). The second way consists in adding the foaming agent directly into the mixer with the other concrete components (TEIXEIRA FILHO; TEZUKA [5]). The autoclave process, which permits to improve the mechanical properties of cellular concrete, sub- jects the material to specific conditions: temperature between 150 and $160{ }^{\circ} \mathrm{C}$ and pressure between 0.6 and $1.2 \mathrm{MPa}$ (PETRUCCl [6]). In this research, the tested cellular concrete was "aerated" but not autoclaved: the aerating agent was diluted into the different mixtures of the research (i.e. the mechanical action of the mixer caused the foam development and so the unit weight reduction). Henceforth the cellular concrete assessed in this research will be simply named "cellular concrete" and the concrete obtained without aerating agent (i.e. the reference concrete) will be named "conventional concrete".

\subsection{Bond between concrete and rebars}

According to Fusco [7], bond is made up of three parts: adhesion bond, friction bond and mechanical bond. Physicochemical bond that appears on the interface between steel and concrete during cement hydration forms an adhesion resistant force (i.e. adhesion bond) that is opposed to the separation of steel and concrete (FUSCO [7]). Once adhesion bond is overstepped, any relative displacement between steel and concrete provokes a resistant friction (on condition that transverse pressures applied on steel exist). These transversal pressures can be caused by transverse compressive stresses provoked by loads, shrinkage or expansion of concrete (LEONHARDT; MÖNNIG [8]). Mechanical bond results from the existence of ribs distributed on steel bars surface, which act like supporting pieces and mobilizing compressive stresses into concrete (FUSCO [7]). In practice is not possible to determine each of the three bond parts separately (FUSCO [7]). Thus, through laboratory tests and for most of the projects, global average bond values are determined: microscopic scale study is not necessary (FUSCO [7]). In this paper the bond values presented are global average values (i.e. including the three parts above presented).

\subsection{Pull-out tests using lightweight concrete}

\subsubsection{Piyamaikongdech [9]}

Piyamaikongdech [9] studied a cellular concrete containing an aerating agent and glass fibers: the unit weight was equal to 1450 $\mathrm{kg} / \mathrm{m}^{3}$ and the water/cement ratio was equal to 0.44 . It should be noted that the material studied by Piyamaikongdech [9] does not include coarse aggregate (contrary to the material studied in this paper). Pull-out tests of steel rebars of $12.7 \mathrm{~mm}$ diameter were carried out. According to Piyamaikongdech [9] the maximum bond stresses $\left(\tau_{\text {bu }}\right)$ were between $1.06 \mathrm{MPa}$ (for $\gamma_{28}=1388 \mathrm{~kg} / \mathrm{m}^{3}$ ) and 4.11 MPa (para $\left.\gamma_{28}=1569 \mathrm{~kg} / \mathrm{m}^{3}\right)$.

\subsubsection{Oliveira [10]}

Oliveira [10] studied bond phenomenon between steel rebar of $10 \mathrm{~mm}$ diameter and lightweight concrete. In order to reduce the density of fresh concrete $\left(\gamma_{0}\right)$, aerating agent, plastic residues and tire fragments (as partial substitution of coarse aggregates) were used. Varying the coarse aggregate type and setting the water/cement ratio at 0.61 , the maximum bond stresses $\left(\tau_{\text {bu }}\right)$ were between $0.84 \mathrm{MPa}$ (for $\gamma_{28}=1779 \mathrm{~kg} / \mathrm{m}^{3}$ ) and $1.48 \mathrm{MPa}\left(\right.$ para $\gamma_{28}=1611 \mathrm{~kg} /$ $\mathrm{m}^{3}$ ). As mentioned by Oliveira [10] $\tau_{\text {bu }}$ corresponds to the arithmetic average of two specimens. 


\section{Materials of the research}

\subsection{Concrete materials}

Three mixtures were studied in this research: Mix1 $\left(\gamma_{28}=2255 \mathrm{~kg} /\right.$ $\mathrm{m}^{3}$, reference mixture), Mix2 $\left(\gamma_{28}=1565 \mathrm{~kg} / \mathrm{m}^{3}\right.$, mixture containing aerating agent $)$ and $\operatorname{Mix} 3\left(\gamma_{28}=1510 \mathrm{~kg} / \mathrm{m}^{3}\right.$, mixture containing aerating agent). Characterizations of fine aggregate (FA) and coarse aggregate (CA) are presented in Table 1. The cement type used was CP II-Z32, as described by ABNT NBR 11578:1991 [15] (i.e. Portland Cement blended with pozzolan material and presenting a 28-day-old compressive strength at least equal to $32 \mathrm{MPa}$ ). The three mixtures of the research contain a water-reducing (high

\section{Table 1}

Characterization of fine aggregate (FA) and coarse aggregate (CA)

\begin{tabular}{|c|c|c|}
\hline Property & FA & CA \\
\hline Bulk density according to NBR NM 52:2009 [1 1 ] e NBR NM 45:2006 [12] $\left(\mathrm{g} / \mathrm{cm}^{3}\right)$ & 1.59 & 1.48 \\
\hline Maximum characteristic size according to NBR NM 248:2003 [13] (mm) & 1.18 & 9.50 \\
\hline Fineness modulus according to NBR NM 248:2003 [13] & 1.79 & 5.70 \\
\hline
\end{tabular}

\section{Table 2}

Mixture proportions (Mix 1, Mix 2 and Mix 3)

\begin{tabular}{|c|c|}
\hline Components & Ratio (by mass) \\
\hline Cement: Fine aggre.: Coarse aggre. & $1: 2.9: 2.1$ \\
\hline Water / Cement & 0.63 \\
\hline Polyp. fibers / Water & 0.0023 \\
\hline Admixture / Water & 0.0083 \\
\hline MMix1 : M Mix2 : M Mix3 & $0: 1: 2$ \\
\hline Note: $\mathrm{M}_{\mathrm{i}}=$ mass of aerating agent added into the mixture "i" & \\
\hline
\end{tabular}

Table 3

Values of $\gamma_{0}$ and $\gamma_{28}$ for Mix 1, Mix2 and Mix3 $\left(\mathrm{kg} / \mathrm{m}^{3}\right)$

\begin{tabular}{|c|c|c|c|c|c|c|}
\hline \multirow{2}{*}{ Specimen } & \multicolumn{2}{|c|}{ Mix 1} & \multicolumn{2}{|c|}{ Mix2 } & \multicolumn{2}{|c|}{ Mix3 } \\
\hline & $\gamma_{0}$ & $\gamma_{28}$ & $\gamma_{0}$ & $\gamma_{28}$ & $\gamma_{0}$ & $\gamma_{28}$ \\
\hline 1 & 2285 & 2282 & 1646 & 1576 & 1534 & 1471 \\
\hline 2 & 2171 & 2180 & 1636 & 1560 & 1582 & 1528 \\
\hline 3 & 2219 & 2228 & 1646 & 1569 & 1569 & 1512 \\
\hline 4 & 2238 & 2235 & 1655 & 1579 & 1642 & 1579 \\
\hline 5 & 2305 & 2308 & 1642 & 1557 & 1557 & 1487 \\
\hline 6 & 2305 & 2314 & 1636 & 1557 & 1544 & 1477 \\
\hline 7 & 2311 & 2317 & 1642 & 1566 & 1569 & 1493 \\
\hline 8 & 2209 & 2209 & 1633 & 1563 & 1525 & 1458 \\
\hline 9 & 2219 & 2219 & 1639 & 1557 & 1582 & 1522 \\
\hline 10 & - & - & - & - & 1614 & 1553 \\
\hline 11 & - & - & - & - & 1569 & 1509 \\
\hline 12 & - & - & - & - & 1598 & 1534 \\
\hline Av. & 2251 & 2255 & 1642 & 1565 & 1574 & 1510 \\
\hline SD & 51 & 51 & 7 & 8 & 33 & 36 \\
\hline $\mathrm{CV}$ & 2.27 & 2.27 & 0.41 & 0.54 & 2.12 & 2.35 \\
\hline
\end{tabular}


Table 4

Compressive strength of research concretes at 28 days (MPa)

\begin{tabular}{|c|c|c|c|}
\hline Specimen & Mix1 & Mix2 & Mix3 \\
\hline 1 & 25.73 & 2.48 & 1.39 \\
\hline 2 & 21.80 & 2.46 & 1.58 \\
\hline 3 & 29.81 & 2.58 & 1.40 \\
\hline 4 & 26.17 & 2.65 & 1.74 \\
\hline 5 & 24.00 & 2.49 & 1.37 \\
\hline 6 & 22.08 & 2.72 & 1.40 \\
\hline 7 & - & - & 1.54 \\
\hline fcm & 24.93 & 2.56 & 0.21 \\
\hline SD & 2.99 & 0.11 & 13.74 \\
\hline
\end{tabular}

range) admixture made from sulfonated naphthalene and presenting a density equal to $1.19 \mathrm{~g} / \mathrm{cm}^{3}$. In order to obtain cellular concrete (Mix2 and Mix3), a protein-based aerating agent with a density equal to $1.01 \mathrm{~g} / \mathrm{cm}^{3}$ was used. In order to limit concrete shrinkage effects, polypropylene fibers were added into the three mixtures of the research.

\subsection{Steel reinforcement}

All the reinforcements of the research specimens were made with CA-60 steel rebars (i.e. $\mathrm{f}_{\mathrm{yk}}=600 \mathrm{MPa}$ ). All the rebars diameter was equal to $4.2 \mathrm{~mm}$.

\subsection{Mixture proportions and concrete characterization}

Table 2 presents material proportions of the three mixtures of the research (for a total volume of concrete equal to $1.0 \mathrm{~m}^{3}$ ). Mix 1 does not include aerating agent whereas Mix2 includes half quantity of aerating agent (compared with Mix3). Characterization specimens of the three mixtures were molded and cured according to the recommendations of ABNT NBR 5738:2015 [16]. Table 3 shows the different values of $\gamma_{0}$ e $\gamma_{28}$ for the three mixtures. Consistency of fresh mixtures was determined following ABNT NBR NM 67:1998 [17] recommendations. Measured slump of Mix1, Mix2 and Mix3 was equal to $140 \mathrm{~mm}, 215 \mathrm{~mm}$ and $260 \mathrm{~mm}$, respectively. The average 28-day-old compressive strength $\left(f_{\mathrm{cm}}\right)$ of each concrete was determined following ABNT NBR 5739:2007 [18] recommendations. Results are presented in Table 4.

\section{Experimental program}

The carried out experiments consist in pulling-out single steel rebars ("Bar" type specimen) or rebars provided with a welded transverse rebar ("T" type specimen) partially submerged in concrete cylinders. All steel rebars used have a nominal diameter $(\varnothing)$ equal to $4.2 \mathrm{~mm}$. Cylinder molding was made following the same procedure of the concrete characterization specimens (see item 3.3). During pull-out tests, tensile force $\left(F_{t}\right)$ and relative translation between steel and concrete $(\Delta)$ were recorded.

\section{1 "Bar » type specimens}

"Bar" type specimen is presented in Figure 1. Steel rebar is partially submerged in a concrete cylinder having a $10.00 \mathrm{~cm}$ diameter and a $20.00 \mathrm{~cm}$ height. The bond length $\left(I_{b}\right)$ is equal to $50 \%$ of the cylinder height. Remaining part of the rebar located inside the cylinder is separated from concrete through a PVC tube of $10.00 \mathrm{~cm}$ length. As recommended by RILEM [19], PVC tube was placed at the loading end of the cylinder (i.e at the zone where bond stresses are significantly increased by the cylinder compression). Twenty-one "Bar" type specimens were molded and the distribution for each mixture is presented in Table 5. Furthermore, in

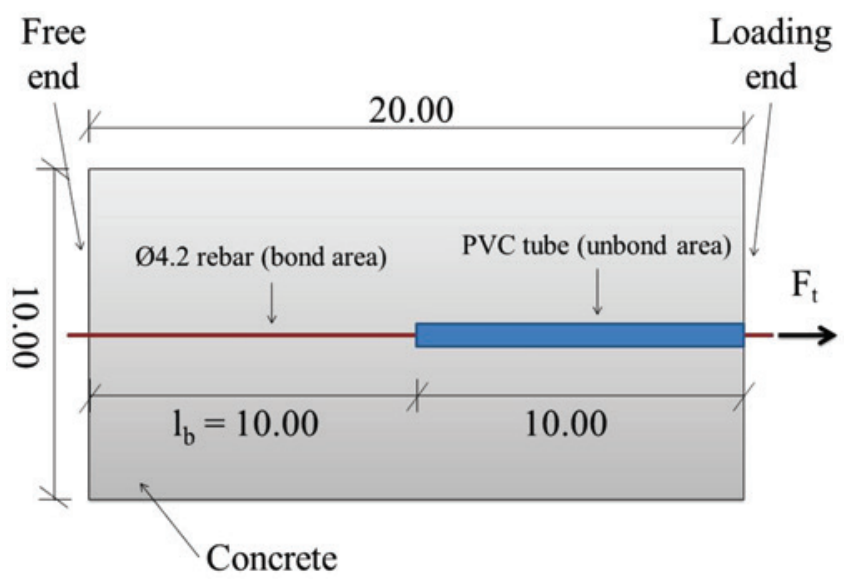

Note: $I_{b}$ : bond length; $F_{\dagger}$ : pull-out force. All dimensions in $\mathrm{cm}$

Figure 1

"Bar" type specimen (longitudinal section) 
Table 5

Description of the research samples

\begin{tabular}{|c|c|c|c|}
\hline Specimen & Type & Mixture & Quantity (specimens) \\
\hline$A B 1$ & "Bar" & \multirow{2}{*}{ Mix 1} & 6 \\
\hline AT1 & "T" & & 6 \\
\hline$A B 2$ & "Bar" & \multirow{2}{*}{ Mix2 } & 9 \\
\hline AT2 & "T" & & 9 \\
\hline AB3 & "Bar" & \multirow{2}{*}{ Mix3 } & 6 \\
\hline AT3 & "T" & & 6 \\
\hline$A B 1-S$ & "Bar" & \multirow{2}{*}{ Mix 1} & $3 *$ \\
\hline AT1-S & "T" & & $3 *$ \\
\hline AB3-S & "Bar" & \multirow{2}{*}{ Mix3 } & $3 *$ \\
\hline AT3-S & "T" & & $3^{*}$ \\
\hline
\end{tabular}

order to study the steel rebar strain during the test, six specimens were molded and each one of them was equipped with two strain gauges (see Figure 2).

\section{2 " ${ }^{\prime \prime} "$ type specimen}

Reinforcement of "T" type specimens was obtained cutting a type $60-C A$ steel grid presenting a mesh size of $10.00 \mathrm{~cm} \times 10.00 \mathrm{~cm}$. The careful cutting of the grid did not suppress entirely transverse rebars unwanted for the test. Thus, residues of cut rebars are present all along the main rebar of the specimen (see Figure 3 ). In order to limit the influence of these residues on bond between reinforcement and concrete, the transverse rebar was placed in the middle of the concrete cylinder, in such a way that residues are located at the ends of the cylinder (see Figure 3). Two PVC

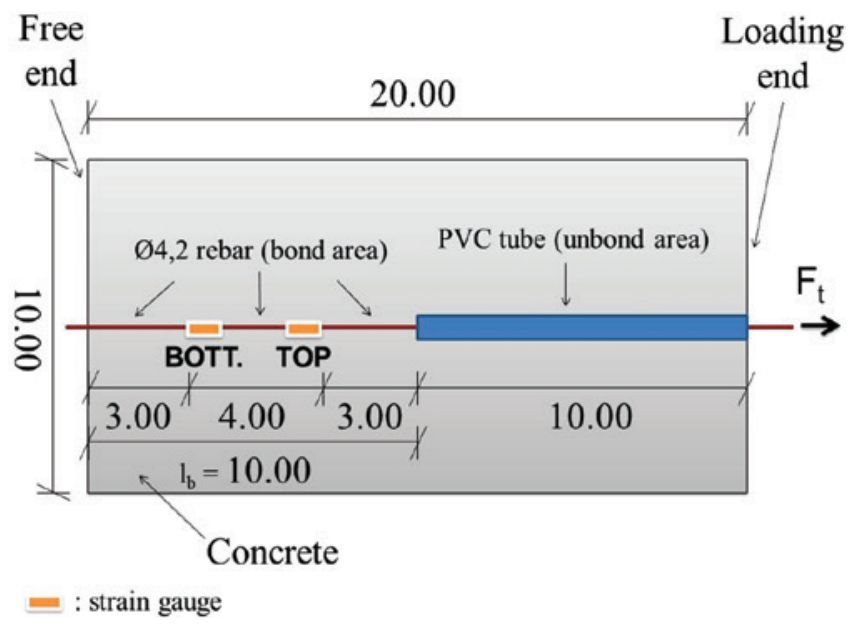

Note: $\mathrm{I}_{\mathrm{b}}$ : bond length; $F_{t}$ : pull-out force. All dimensions in $\mathrm{cm}$

\section{Figure 2}

"Bar" type specimen equipped with strain gauges (longitudinal section) tubes of $5.00 \mathrm{~cm}$ length placed on both sides of the transverse rebar permitted to get a longitudinal bond length equal to 10.00 $\mathrm{cm}\left(\mathrm{I}_{\mathrm{b}}\right)$. Also the PVC tube located close to the loading end of the cylinder (see "PVC A" in Figure 3) limited the influence of cylinder compression on the tensile force $\left(F_{t}\right)$ recording. The transverse rebar $\left(t_{b}\right)$ has a total length of $9.50 \mathrm{~cm}$. Twenty-one "T" type specimens were molded and the distribution for each mixture is presented in Table 5. Furthermore, in order to study the longitudinal steel rebar strain during the test, six specimens were molded and each one of them was equipped with two strain gauges (see Figure 4).

\subsection{Specimen nomenclature and sample description}

Table 5 describes the ten samples of the resaerch.

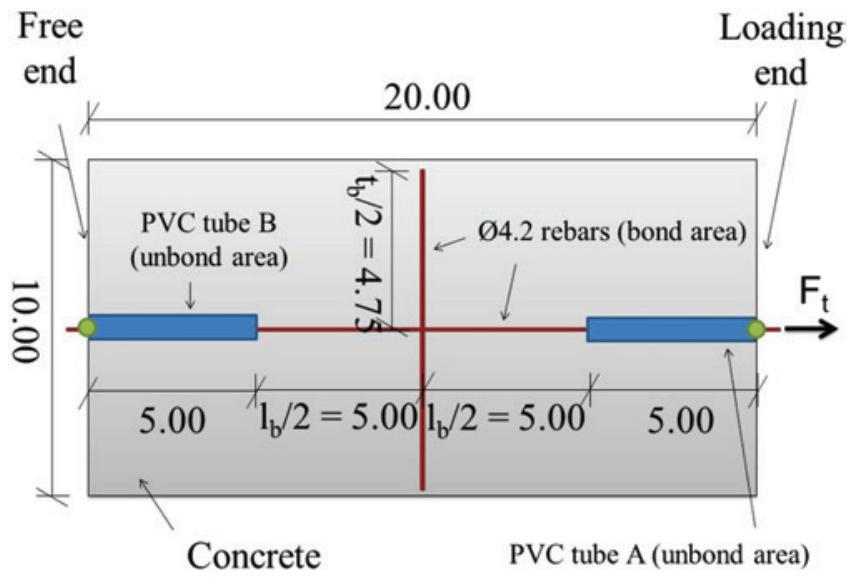

$\mathrm{O}=$ residue of cut rebar

Note: $I_{b}=$ longitudinal bond length; $t_{b}=$ transversal bond length; $\mathrm{F}_{\mathrm{t}}=$ pull-out force. All dimensions in $\mathrm{cm}$

Figure 3

"T" type specimen (longitudinal section) 


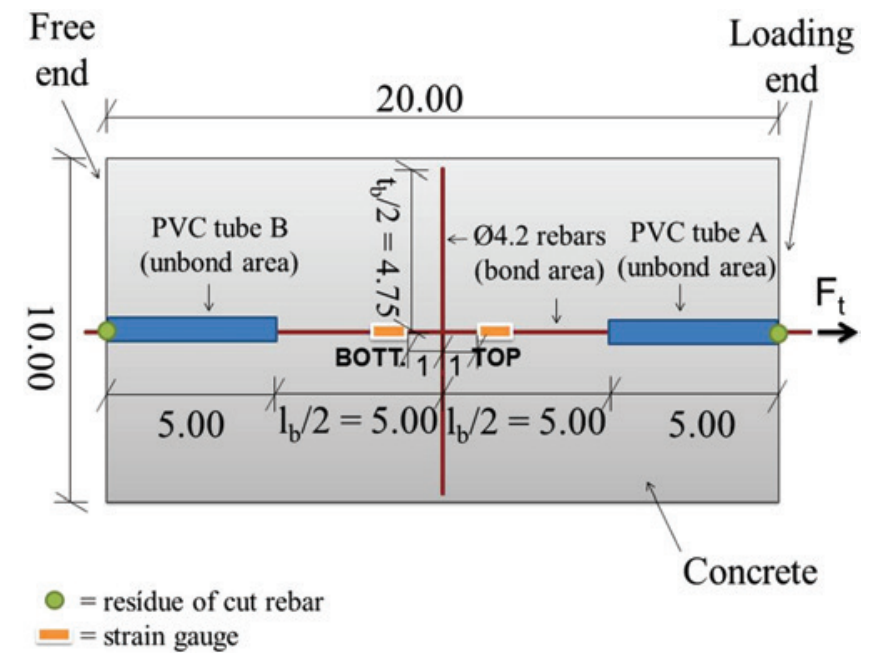

Note: $I_{b}=$ longitudinal bond length; $t_{b}=$ transversal bond length; $\mathrm{F}_{\dagger}=$ pull-out force. All dimensions in $\mathrm{cm}$

\section{Figure 4}

"T" type specimen equipped with strain gauges (longitudinal section)

\subsection{Pull-out system}

Pull-out tests were carried out using a universal testing machine with a maximum capacity of $1000 \mathrm{kN}$. Figure 5 presents the different parts of the pull-out system. A load cell with a capacity of $10 \mathrm{tf}$ was used for the pull-out force measurement. The relative translation between the longitudinal steel rebar and the concrete cylinder was measured using a LVDT fixed to the testing machine with a magnetic stand. All measurements were recorded on a computer using a data acquisition system.

\subsection{Calculation of the ultimate bond stress}

The ultimate bond stress $\left(\tau_{\mathrm{bu}}\right)$ of the "Bar" type specimens was calculated from the division of the maximum tensile force applied during the test $\left(F_{t u}\right)$ by the bond area (i.e. the area of the steel rebar which is in contact with the concrete cylinder) and which is equal to m.Ø. $I_{b}$ :

$\tau_{\mathrm{bu}}=100 . \mathrm{F}_{\mathrm{tu}} /\left(\pi \cdot \varnothing \cdot \mathrm{I}_{\mathrm{b}}\right)$

where $\tau_{\mathrm{bu}}$ is the ultimate bond stress (MPa); $F_{\mathrm{tu}}$ is the maximum tensile force $(\mathrm{kN})$; $\varnothing$ is the nominal rebar diameter $(\mathrm{mm})$ and $\mathrm{I}_{\mathrm{b}}$ is the bond length $(\mathrm{cm})$.

\section{Test results and discussion}

\subsection{Maximum pull-out force $\left(F_{t u}\right)$ and ultimate bond stress $\left(\tau_{b u}\right)$}

Table 6 and Table 7 present the principal quantitative results of the research. Concerning type "Bar" specimens, reduction of $\gamma_{28}$ provokes a large decrease of $F_{\text {tum }}$ : there is a decrease of $6.00 \mathrm{kN}$ (92\%) between AB1 and AB2 samples, and one of $6.36 \mathrm{kN}$ (98 \%) between $A B 1$ and $A B 3$ samples. The same observations can be done concerning the ultimate bond stress $\left(\tau_{\text {bu }}\right)$ : decrease of 4.54 MPa (92 \%) between AB1 and AB2 and decrease of 4.81 MPa (98\%) between $A B 1$ and $A B 3$. The increase of pull-out strength $\left(\mathrm{F}_{\text {tum }}\right)$ coming from the transverse rebar insertion into the concrete cylinder becomes larger when $\gamma_{28}$ decreases: there is an increase of $3.64 \mathrm{kN}(56 \%)$ between AB1 and AT1 samples, an increase of $4.91 \mathrm{kN}(982 \%)$ between AB2 and AT2 and an increase of $2.83 \mathrm{kN}$ (2021\%) between AB3 and AT3. Concerning AB1-S and AB3-S, strain gauges presence degraded the bond area and made impossible $I_{b}$ measurement and so $\tau_{b u}$ calculation. Thus the quantitative results of AB1-S and AB3-S samples are not considered in this research. Concerning "T" type samples, there is a decrease of only $0.36 \mathrm{kN}(4 \%)$ between AT1 and AT1-S and one of $0.41 \mathrm{kN} \mathrm{(14 \% )}$ between AT3 and AT3-S. Thereby even though strain gauges reduced the bond length $\left(I_{b}\right)$, quantitative results of AT1-S and AT3-S samples are considered in this research.

\subsection{Failure modes}

\subsubsection{Failure modes of $A B 1, A B 2$ and $A B 3$ samples}

For $100 \%$ of $A B 1, A B 2$ and $A B 3$ samples, the pull-out test did not provoke concrete cylinder cracking: failure occurred through the rebar translation (Figure 6). Concerning the AB2 sample, three specimens $(33 \%)$ failed only with the pre-load $(P)$ necessary to fix the specimen to the testing machine. The same failure mode occurred for $100 \%$ of $\mathrm{AB} 3$ sample.

\subsubsection{Failure mode of AT1 sample}

For $100 \%$ of AT1 sample the failure occurred at the level of the longitudinal rebar, outside the concrete cylinder (Figure 7-a and 7-b) without concrete cracking (Figure 7-c).

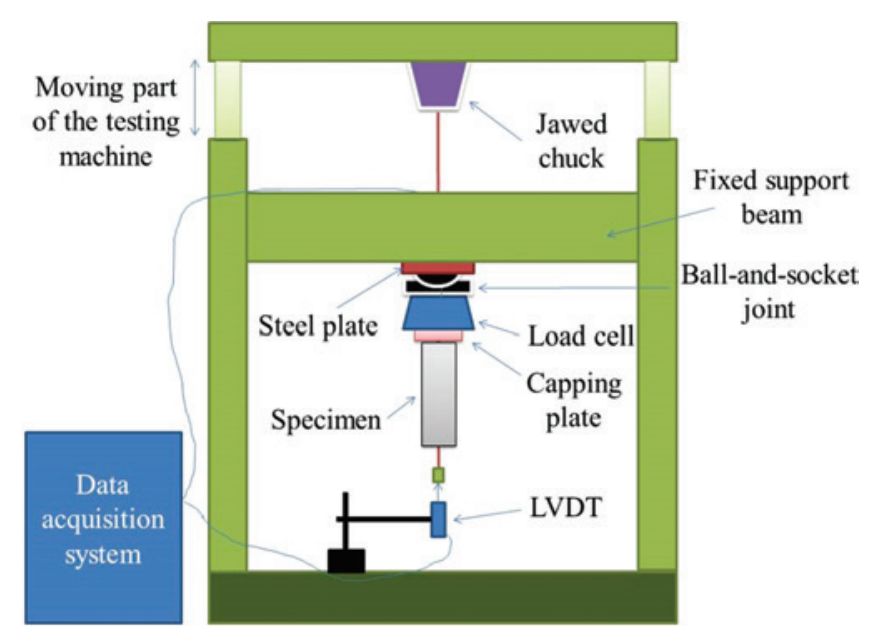

Note: drawing out of scale

Figure 5

Schematic drawing of the pull-out system 
Table 6

Quantitative results of pull-out tests (part 1/2)

\begin{tabular}{|c|c|c|c|c|c|c|}
\hline Sample & Spec. & $\mathrm{I}_{\mathrm{b}}(\mathrm{cm})$ & $F_{\mathrm{fu}}(\mathrm{kN})$ & $\mathrm{F}_{\mathrm{tum}}(\mathrm{kN})$ & $\tau_{\mathrm{bu}}(\mathrm{MPa})$ & $\tau_{\text {bum }}(\mathrm{MPa})$ \\
\hline \multirow{6}{*}{$A B 1$} & 1 & $10.10^{* *}$ & 5.38 & \multirow{6}{*}{6.50} & 2.48 & \multirow{6}{*}{$(C V \stackrel{4.92}{=} 9.65 \%)$} \\
\hline & $(\mathrm{CV}=9.00 \%)$ & 4.04 & 1.58 & & 2.46 & \\
\hline & 2 & $9.94 * *$ & 6.84 & & 5.22 & \\
\hline & 3 & $10.09^{* *}$ & 6.33 & & 4.75 & \\
\hline & 4 & $9.93 * *$ & 6.90 & & 5.27 & \\
\hline & 5 & $9.94^{* *}$ & 6.87 & & 5.24 & \\
\hline \multirow{6}{*}{ AT1 } & 1 & $10.08^{* *}$ & 9.84 & \multirow{6}{*}{$\begin{array}{c}10.14 \\
(C V=2.23 \%)\end{array}$} & - & \multirow{6}{*}{ - } \\
\hline & 2 & $10.11^{* *}$ & 10.13 & & - & \\
\hline & 3 & $10.07^{* *}$ & 9.95 & & - & \\
\hline & 4 & $10.37^{* *}$ & 10.48 & & - & \\
\hline & 5 & $10.07^{*}$ & 10.21 & & - & \\
\hline & 6 & $10.09 * *$ & 10.24 & & - & \\
\hline \multirow{3}{*}{ ATI-S } & 1 & $10.15^{*}$ & 9.68 & \multirow{3}{*}{$(\mathrm{CV} \stackrel{9.78}{=2.48 \%)}$} & - & \multirow{3}{*}{ - } \\
\hline & 2 & $10.10^{*}$ & 9.61 & & - & \\
\hline & 3 & $10.14^{*}$ & 10.06 & & - & \\
\hline \multirow{9}{*}{ AB2 } & 1 & $9.99 * *$ & 0.29 & \multirow{9}{*}{$(C V=63.69 \%)$} & 0.22 & \multirow{9}{*}{$\begin{array}{c}0.38 \\
(\mathrm{CV}=63.49 \%)\end{array}$} \\
\hline & 2 & $10.00 * *$ & 0.91 & & 0.69 & \\
\hline & 3 & $9.95 * *$ & 0.43 & & 0.33 & \\
\hline & 4 & $10.04^{* *}$ & 0.86 & & 0.65 & \\
\hline & 5 & $10.07^{* *}$ & 0,86 & & 0.65 & \\
\hline & 6 & $10.02^{* *}$ & 0.44 & & 0.33 & \\
\hline & 7 & $10.06^{* *}$ & 0.09 & & 0.07 & \\
\hline & 8 & $10.05^{* *}$ & 0.55 & & 0.41 & \\
\hline & 9 & $10.00^{* *}$ & 0.09 & & 0.07 & \\
\hline \multirow{9}{*}{ AT2 } & 1 & $10.11^{*}$ & 5.25 & \multirow{9}{*}{$(C V \stackrel{5.41}{=} 6.54 \%)$} & - & \multirow{9}{*}{-} \\
\hline & 2 & $10.02^{*}$ & 5.03 & & - & \\
\hline & 3 & $10.14^{*}$ & 5.53 & & - & \\
\hline & 4 & 10.10* & 5.54 & & - & \\
\hline & 5 & $10.08^{*}$ & 5.55 & & - & \\
\hline & 6 & $10.16^{*}$ & 5.39 & & - & \\
\hline & 7 & $9.91^{* *}$ & 4.83 & & - & \\
\hline & 8 & $10.01^{*}$ & 6.07 & & - & \\
\hline & 9 & $10.16^{*}$ & 5.54 & & - & \\
\hline
\end{tabular}

Note: $I_{b}=$ bond length; Ftu $(m)=$ ultimate pull-out force (average); $\tau_{\text {bu }}(m)=$ ultimate bond strength (average); CV $=$ coefficient of variation. Bond length $\left(I_{b}\right)$ measured on the rebar before the test $\left({ }^{*}\right)$ or on the concrete after the test and cylinder splitting $\left({ }^{* *}\right)$

Table 7

Quantitative results of pull-out tests (part 2/2)

\begin{tabular}{|c|c|c|c|c|c|c|}
\hline Sample & Spec. & $\mathrm{I}_{\mathrm{b}}(\mathrm{cm})$ & $F_{\mathrm{fu}}(\mathrm{kN})$ & $F_{\text {tum }}(k N)$ & $\tau_{\mathrm{bu}}(\mathrm{MPa})$ & $\tau_{\text {bum }}(\mathrm{MPa})$ \\
\hline \multirow{6}{*}{ AB3 } & 1 & $9.81^{* *}$ & 0.09 & \multirow{6}{*}{$\begin{array}{c}0.14 \\
(\mathrm{CV}=87.48 \%)\end{array}$} & 0.07 & \multirow{6}{*}{$\begin{array}{c}0.11 \\
(\mathrm{CV}=84.20 \%)\end{array}$} \\
\hline & 2 & $10.03 * *$ & 0.09 & & 0.07 & \\
\hline & 3 & $10.00 * *$ & 0.09 & & 0.07 & \\
\hline & 4 & $10.11^{*}$ & 0.09 & & 0.07 & \\
\hline & 5 & $9.95^{* *}$ & 0.09 & & 0.07 & \\
\hline & 6 & $9.98^{* *}$ & 0.39 & & 0.29 & \\
\hline \multirow{6}{*}{ AT3 } & 1 & $10.14^{*}$ & 2.81 & \multirow{6}{*}{$(\mathrm{CV}=2.97$} & - & \multirow{6}{*}{ - } \\
\hline & 2 & $9.86^{* *}$ & 2.88 & & - & \\
\hline & 3 & $10.07^{*}$ & 3.15 & & - & \\
\hline & 4 & $10.15^{*}$ & 2.82 & & - & \\
\hline & 5 & $10.00^{*}$ & 3.27 & & - & \\
\hline & 6 & $10.08^{* *}$ & 2.86 & & - & \\
\hline \multirow{3}{*}{ AT3-S } & 1 & $10.10^{* *}$ & 2.83 & \multirow{3}{*}{$\begin{array}{c}2.56 \\
(C V=10.96 \%)\end{array}$} & - & \multirow{3}{*}{ - } \\
\hline & 2 & $10.01^{* *}$ & 2.27 & & - & \\
\hline & 3 & $10.07^{* *}$ & 2.59 & & - & \\
\hline
\end{tabular}




\subsubsection{Failure modes of AT2 and AT3 samples}

Concerning the AT2 sample, seven specimens (78\%) failed through the longitudinal rebar translation and the transverse rebar bending (Figure 8-a and 8-b), which provoked longitudinal and transverse cracking of the concrete cylinder (Figure 8-c). For 22 $\%$ of the same sample (i.e. two specimens) the failure occurred at the level of the weld between the longitudinal and transverse rebars (Figure 8-d and 8-e) without concrete cracking (Figure 8-f). Concerning the AT3 sample, six specimens (100\%) failed through the longitudinal rebar translation and the transverse rebar bending (Figure 9-a and 9-b), which also provoked longitudinal and transverse cracking of the concrete cylinder (Figure 9-c). Specimens of AT3 presented a lower transverse rebar bending than specimens of AT2 (compare Figure 8-b with Figure 9-b), which confirms the pullout strength reduction of the transverse rebar when $\gamma_{28}$ decreases (i.e. when the aerating agent ratio of the mixture increases).

\subsubsection{Failure mode of AT1-S sample}

For $100 \%$ of AT1-S sample (i.e. three specimens), the failure oc-

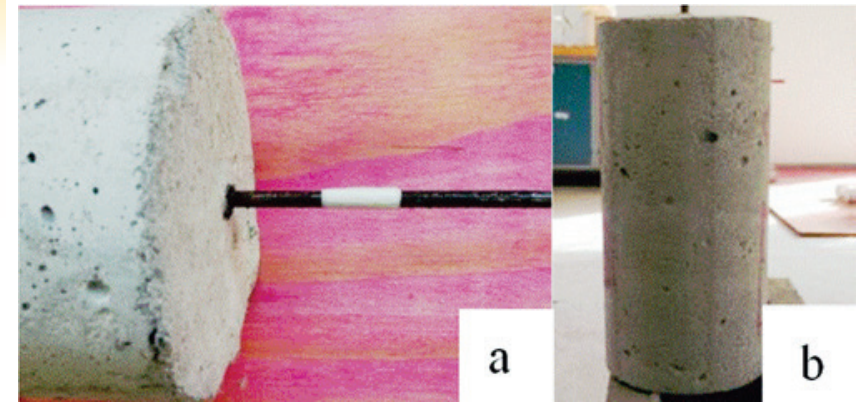

Note: translation of the rebar (a) without concrete cracking (b)

\section{Figure 6}

Failure mode of $A B 1, A B 2$ and $A B 3$ samples

curred at the level of the weld between the longitudinal and transverse rebars (Figure 10-b) and not outside the concrete cylinder such as AT1 sample specimens (Figure 7-a e 7-b). As indicated in Figure $10-c$, it is notable that cylinders did not crack: this situation is the same of AT1 sample (see Figure 7-c).

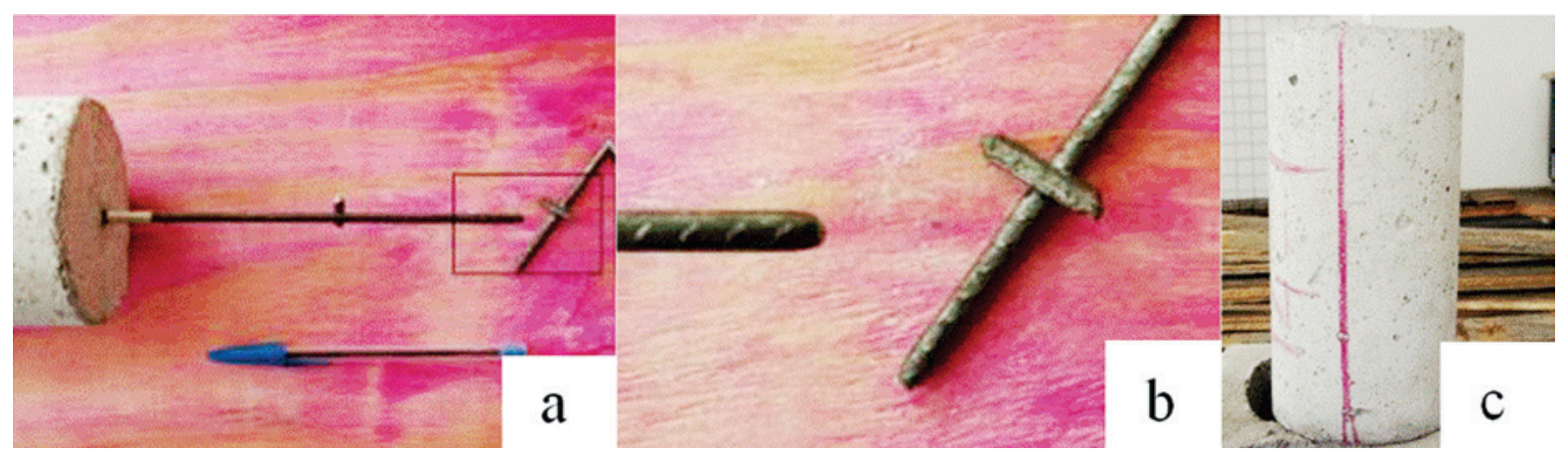

Note: failure of the longitudinal rebar outside the concrete cylinder $(a, b)$ without concrete cracking (c)

\section{Figure 7}

Failure mode of AT1 sample
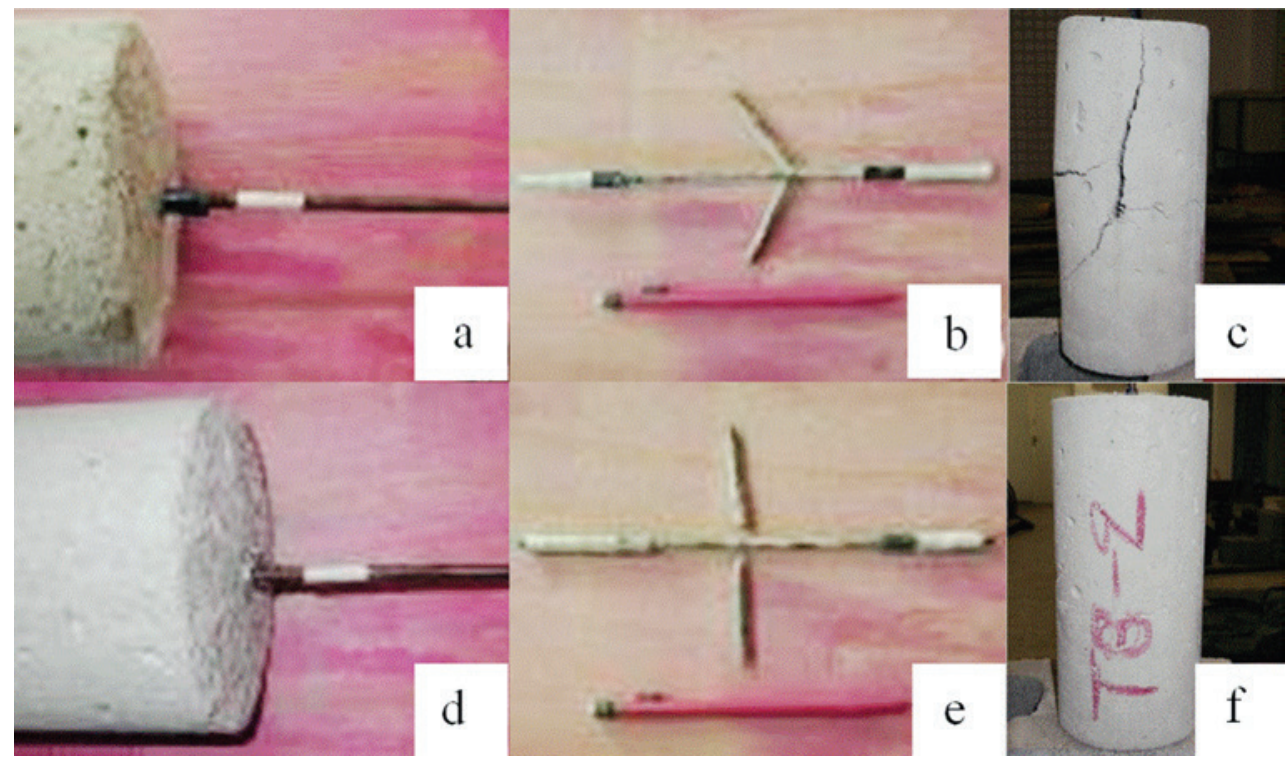

Note: for $78 \%$ of the sample, longitudinal rebar translation and transverse rebar bending $(a, b)$ with longitudinal and transverse cracking of concrete (c). For $22 \%$ of the sample, failure at the level of the weld between the longitudinal and transverse rebars (d, e), without concrete cracking ( $f$ )

\section{Figure 8}

Failure modes of AT2 sample 


\subsubsection{Failure mode of AT3-S sample}

For $100 \%$ of AT3-S sample (three specimens) the failure mode was identical to the one of AT3 sample: the failure occurred through the longitudinal rebar translation and the transverse rebar bending (Figure 11-a and 11-b). Also, such as AT3 sample specimens, specimens of AT3-S sample cracked longitudinally and transversally (Figure 11-c).

\section{$5.3 \quad F_{t}-\Delta$ diagrams}

Diagrams of Figure 12 show the evolution of the tensile force ap-
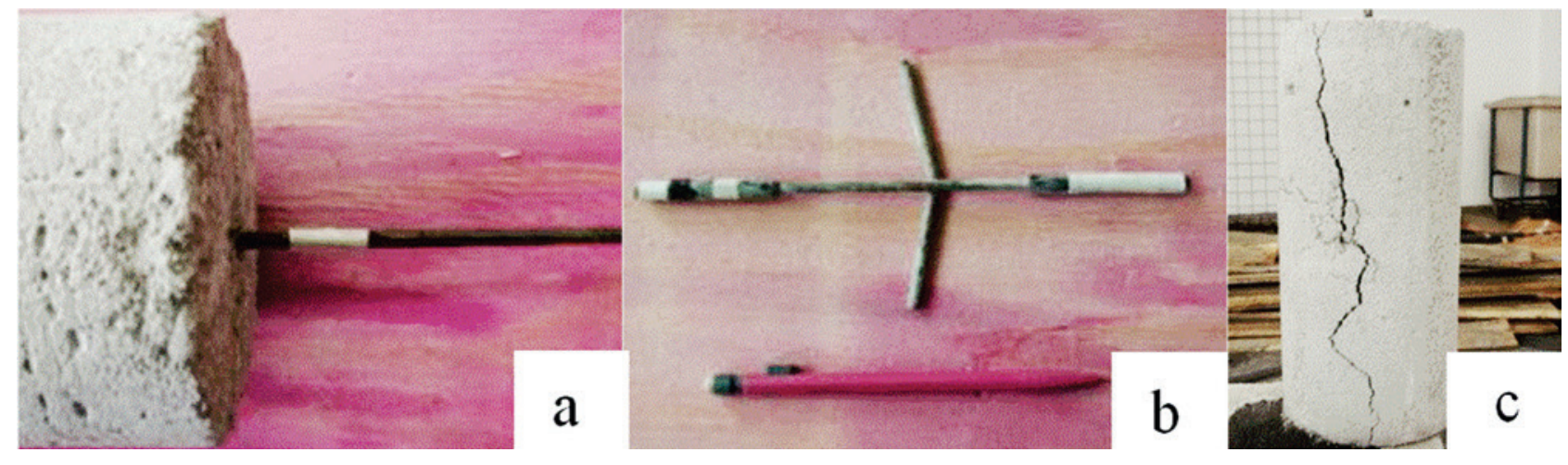

Note: longitudinal rebar translation and transverse rebar bending $(a, b)$ with longitudinal and transverse cracking of concrete (c)

\section{Figure 9}

Failure mode of AT3 sample
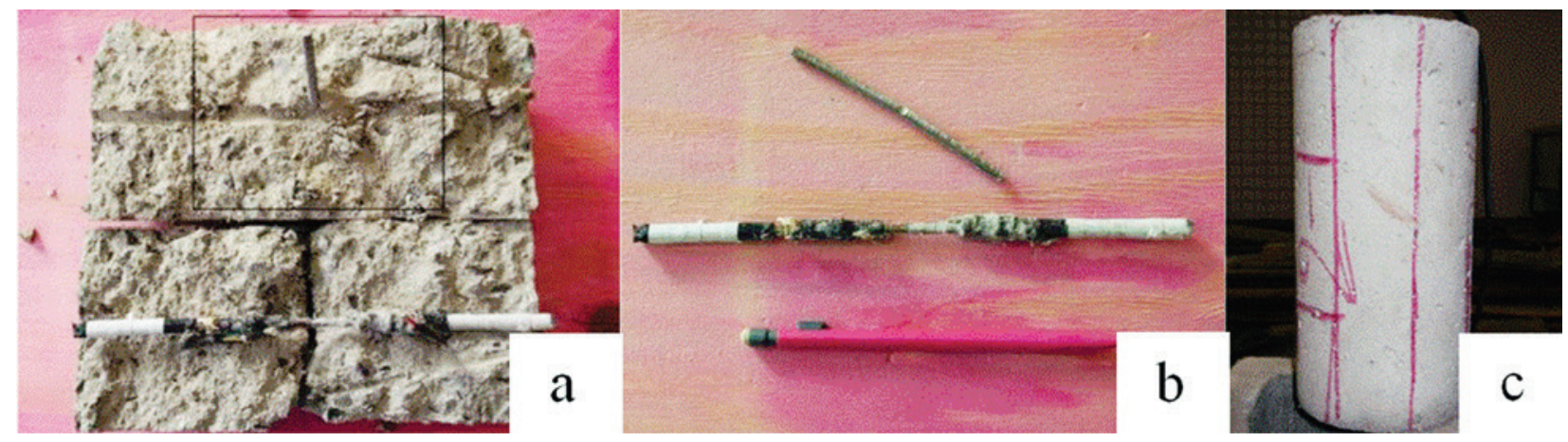

Note: failure at the level of the weld between the longitudinal and transverse rebars ( $a, b)$, without concrete cracking (c)

\section{Figure 10}

Failure mode of AT1-S sample

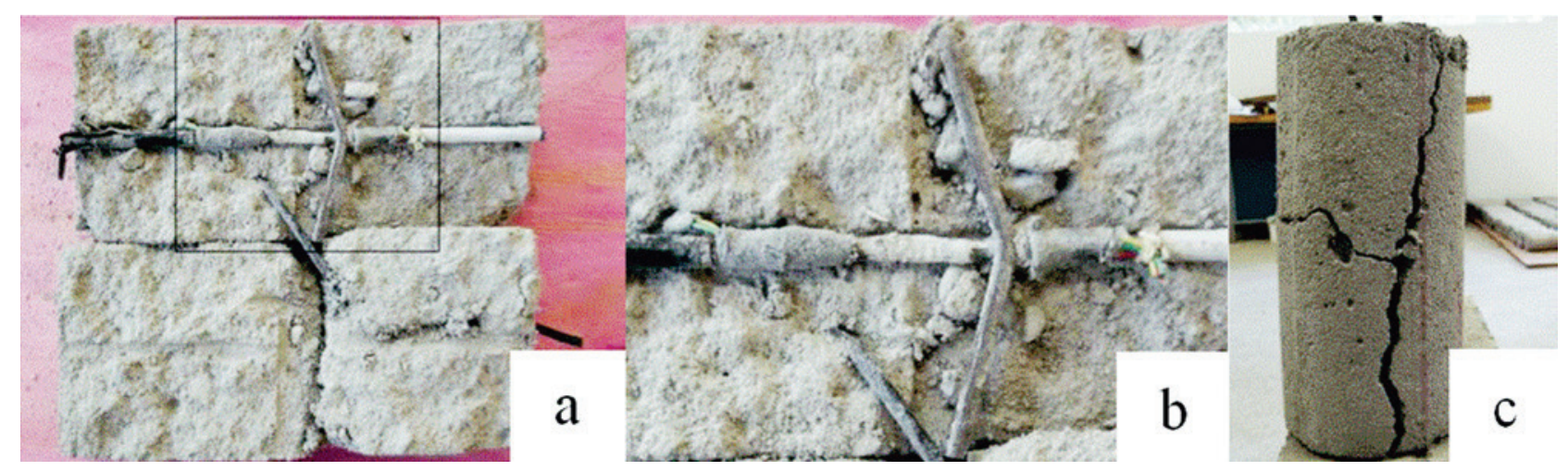

Note: longitudinal rebar translation and transverse rebar bending $(a, b)$ with longitudinal and transverse cracking of concrete (c)

\section{Figure 11}

Failure mode of AT3-S sample 
plied during the test $\left(F_{t}\right)$ in function of the longitudinal rebar translation $(\Delta)$ and the sample type. Each diagram corresponds to arithmetic average values.

\subsection{1 $\quad F_{t}-\Delta$ diagrams of $A B 1, A B 2$ and $A B 3$ samples}

The diagram of $A B 1$ sample is typical of a failure by translation of a rebar into concrete: there is a slight decrease of the curve after the maximum tensile force $\left(\mathrm{F}_{\mathrm{tu}}\right)$. This failure mode is coherent with visual observations made after the research tests (see item 5.2.1). The average diagram of $A B 2$ sample confirms the large bond strength decrease noticed from the quantitative results of the study (see item 5.1). For $100 \%$ of $A B 3$ sample (i.e. six specimens) the translation of the rebar started immediately after the application of the pre-load $(P)$, making impossible to obtain the average diagram.

\subsection{2 $\quad F_{t}-\Delta$ diagrams of AT1 and AT1-S samples}

For $100 \%$ of AT 1 sample (i.e. six specimens) the failure occurred at the level of the longitudinal rebar, outside the concrete cylinder (see item 5.2.2). The LVDT offset from the longitudinal specimen axis (provoked by the sudden failure of the longitudinal rebar) did not enable to elaborate the complete average diagram of the AT1 sample. Thus the diagram is presented only until the maximum tensile force applied $\left(F_{t u}\right)$. Concerning AT1-S, even though failure was brittle for $100 \%$ of the specimens (i.e. failure occurred at the level of the weld between the longitudinal and transverse rebars, see item 5.2.4), the LVDT offset from the longitudinal specimen axis did not happen and data were recorded until the end of the tests. Thus the complete average $F_{t}-\Delta$ diagram of AT1-S sample is presented in Figure 12. It should be noted that AT1 and AT1-S diagrams are relatively similar until $F_{\text {tu }}$ values. So even though strain gauges of AT1-S sample reduced the longitudinal bond length, they did not alter significantly the quantitative results of this sample.

\subsection{3 $\quad F_{t}-\Delta$ diagrams of AT2 and AT3 samples}

For $78 \%$ of AT2 sample (i.e. seven specimens) failure occurred by concrete cracking provoked by the translation of longitudinal and transverse rebars though the concrete cylinder (see item 5.2.3). For two specimens (22\%) failure occurred at the level of the weld

\section{$\mathbf{F}_{\mathrm{t}}(\mathbf{k N})$}

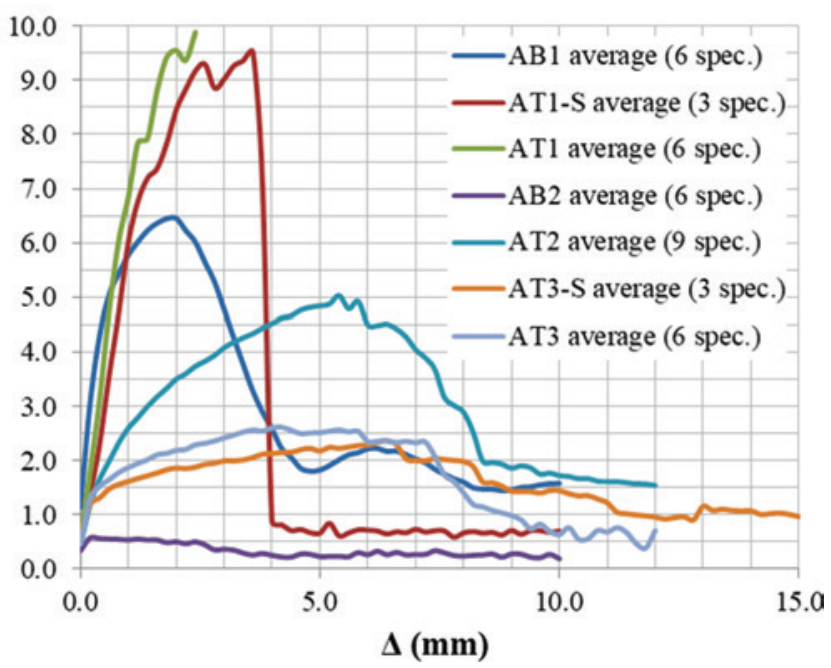

Figure 12

$F_{f}-\Delta$ diagrams between the longitudinal and transverse rebars (see item 5.2.3). Consequently the average diagram of AT2 sample of Figure 12 is more representative of the failure mode provoked by concrete cracking (78\% of the cases) than the one provoked by the weld break. Comparing the average diagram of AT2 sample with the one of AT1 sample, it should be noted that exists a large decrease of $\mathrm{F}_{\mathrm{tu}}$ (maximum force) and an increase of $\Delta_{\mathrm{u}}$ (rebar translation value corresponding to $\mathrm{F}_{\mathrm{tu}}$ ) which reveals the bond strength and concrete stiffness decrease when aerating agent is added into the mixture. For $100 \%$ of AT3 sample (i.e. six specimens) the failure mode was also provoked by concrete cracking. Comparing the average diagram of AT3 sample with the one of AT2 sample, it should be noted that exists a decrease of $F_{t}$, which reveals the decrease of the bond strength when the aerating agent ratio added into the mixture increases.

\subsection{4 $\quad F_{t}-\Delta$ diagrams of AT3-S samples}

For $100 \%$ of AT3-S sample (i.e. three specimens) the failure occurred (like for AT3 sample) by concrete cracking provoked by the translation of longitudinal and transverse rebars though the concrete cylinder. The relative similarity between AT3-S and AT3 average diagram shows that even though strain gauges of AT3-S sample reduced the longitudinal bond length, they did not alter significantly the quantitative results of this sample. This observation is coherent with the ones of items 5.1 and 5.2.5.

\subsection{Steel rebar strain}

Figure 13 presents the evolution of the tensile force applied during the test $\left(F_{t}\right)$ in function of the normal strain of the longitudinal rebar $\left(\varepsilon_{\mathrm{s}}\right)$ and sample type. Obtained diagrams correspond to average values. It should be noted that strain gauges of one AT1-S specimen disconnected from the data acquisition system during the test, so $F_{t}-\varepsilon_{s}$ diagram of AT1-S sample was obtained from only

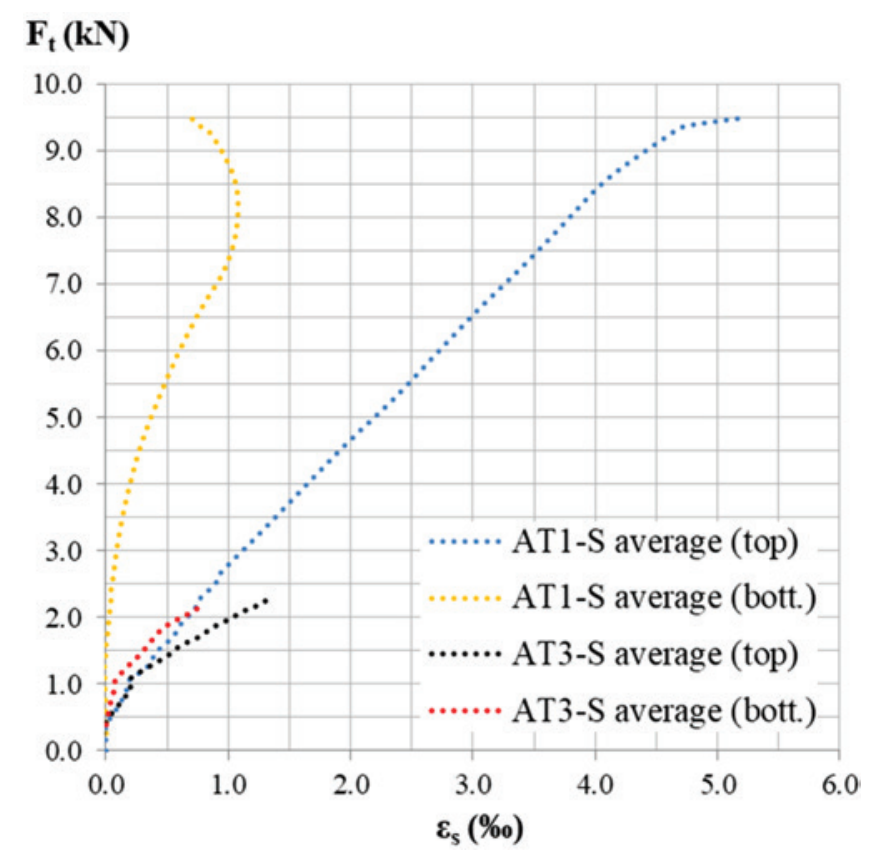

Note: top = top strain gauge; bott. = bottom strain gauge . See Figure 4 for strain gauge locations

\section{Figure 13}

$\mathrm{F}_{\dagger}-\varepsilon_{\mathrm{s}}$ diagrams 
two specimens (against three for AT3-S sample). Figure 13 permits to compare AT1-S and AT3-S longitudinal rebar strain evolution: it should be noted that the difference between the maximum strain value of top strain gauge and the one of the bottom strain gauge decreases when $\gamma_{28}$ is reduced (about $4 \%$ for AT1-S and about $0.5 \%$ for AT3-S). Also for the same value of $F_{t}$, strain gauges of AT3-S sample present higher $\varepsilon_{s}$ values than the ones of AT1-S sample, which confirms the stiffness decrease of concrete when $\gamma_{28}$ is reduced.

\section{Conclusions}

Bond phenomenon between cellular concrete and steel rebar was investigated through pull-out tests. Main results and comments of this study are summarised by the following conclusions.

Between $\gamma_{28}=2255 \mathrm{~kg} / \mathrm{m}^{3}$ (reference concrete) and $\gamma_{28}=1565 \mathrm{~kg} /$ $\mathrm{m}^{3}$ (cellular concrete) the ultimate bond stress underwent a 92 $\%$ decrease and between $\gamma_{28}=2255 \mathrm{~kg} / \mathrm{m}^{3}$ (reference concrete) and $\gamma_{28}=1510 \mathrm{~kg} / \mathrm{m}^{3}$ (cellular concrete) the ultimate bond stress decrease was equal to $98 \%$. Compared with reference concrete these results revealed the influence of the aerating agent in the large bond decrease between $4.2 \mathrm{~mm}$ diameter steel rebars and cellular concrete. Thus for structural applications of cellular concrete, thorough bond phenomenon study with steel reinforcement is an indispensable matter.

Concerning the anchoring system used, the transversal rebar permitted an increase of the maximum pull-out force $\left(F_{\text {tum }}\right)$ when $\gamma_{28}$ was reduced. For $\gamma_{28}=2255 \mathrm{~kg} / \mathrm{m}^{3}$ (reference concrete) the transverse rebar permitted a $F_{\text {tum }}$ increase of $56 \%$, for $\gamma_{28}=1565 \mathrm{~kg} /$ $\mathrm{m}^{3}$ (cellular concrete) the $F_{\text {tum }}$ increase was equal to $982 \%$ and for $\gamma_{28}=1510 \mathrm{~kg} / \mathrm{m}^{3}$ (cellular concrete) the $F_{\text {tum }}$ increase was equal to $2021 \%$. In accordance with the concrete type, the transverse rebar presence changed the failure mode of the different tested specimens: rebar failure outside the concrete cylinder (for the reference concrete) and, in most of the cases, pull-out of the reinforcement without steel failure (for concrete cellular). The different failure modes observed between reference concrete and cellular concrete limit the following conclusion to cellular concrete only: the bond gain provoked by the transverse rebar increases when $\gamma_{28}$ is reduced.

Thus this research revealed that special anchorages (not exclusively straight) like, for example, transverse rebar, have a better mechanical behaviour (i.e. a higher bond strength gain) as soon as the concrete density decreases (i.e. as soon as the aerating agent ratio of the mixture increases).

This above conclusion incites the utilization of special anchorages (e.g. steel grid) in structural cellular concrete elements in order to improve the weak bond strength provided by straight rebars into cellular concrete.

\section{Acknowledgements}

The authors gratefully acknowledge Gethal $®$ for the material providing and their financial support. Coordenação de Aperfeiçoamento de Pessoal de Nível Superior (CAPES) is also gratefully acknowledged for the grant allocated to the first mentioned author.

\section{References}

[1] CARVALHO, R. C.; FIGUEIREDO FILHO, J. R. Cálculo e detalhamento de estruturas usuais de concreto armado: segundo a NBR 6118: 2003. 3. ed. São Carlos: Ed. UFSCar, 2007. 368 p.

[2] ASSOCIAÇÃO BRASILEIRA DE NORMAS TÉCNICAS - ABNT. NBR 8953: concrete for structural use - density, strength and consistence classification. Rio de Janeiro: ABNT, 2015. 3 p.

[3] ROSSIGNOLO, J. A. Concreto leve estrutural: produção, propriedades, microestruturas e aplicações. São Paulo: Pini, 2009. 144 p.

[4] FERREIRA, O. A. R. Concretos celulares espumosos. São Paulo: Departamento de Engenharia Construção Civil da EPUSP, 1987. 20 p. Boletim técnico.

[5] TEIXEIRA FILHO, F. J.; TEZUKA, Y. Considerações sobre algumas propriedades dos concretos celulares espumosos. São Paulo: Escola Politécnica da USP, Departamento de Engenharia de Construção Civil, 1992. 29 p. Boletim técnico.

[6] PETRUCCI, E. G. R. Concreto de cimento Portland. 5. ed. Porto Alegre: Globo, 1978. 307 p.

[7] FUSCO, P. B. Técnica de armar as estruturas de concreto. São Paulo: Pini, 1995. 382 p.

[8] LEONHARDT, F.; MÖNNIG, E. Construções de concreto, volume 1: princípios básicos do dimensionamento de estruturas de concreto armado. Tradução de: David Fridman. Rio de Janeiro: Interciência, 1977. 336 p.

[9] PIYAMAIKONGDECH, A. Ductile lightweight concrete for lightweight structural application. 2007. $183 \mathrm{f}$. Thesis (Master of Science) - Faculty of the Graduate School, University of Texas, Arlington, 2007.

[10] OLIVEIRA, K. R. de S. Aderência da armadura ao concreto leve com adição de resíduos. 2006. 198 f. Dissertação (Mestrado) - Curso de Engenharia Civil, Universidade Federal Fluminense, Niterói, 2006.

[11] ASSOCIAÇÃO BRASILEIRA DE NORMAS TÉCNICAS ABNT. NBR NM 52: fine aggregate - determination of the bulk specific gravity and apparent specific gravity. Rio de Janeiro: ABNT, 2009. 6 p.

[12] ASSOCIAÇÃO BRASILEIRA DE NORMAS TÉCNICAS ABNT. NBR NM 45: aggregates - determination of the unit weight and air-void contents. Rio de Janeiro: ABNT, 2006. 8 p.

[13] ASSOCIAÇÃO BRASILEIRA DE NORMAS TÉCNICAS ABNT. NBR NM 248: aggregates - sieve analysis of fine and coarse aggregates. Rio de Janeiro: ABNT, 2003. 6 p.

[14] LIMA, T. L. Estudo das propriedades físicas e mecânicas do concreto celular estrutural. 2015. Dissertação (Mestrado) Curso de Estruturas e Construção Civil, Departamento de Engenharia Civil, Universidade Federal de São Carlos, São Carlos, 2015. Dissertação em andamento.

[15] ASSOCIAÇÃO BRASILEIRA DE NORMAS TÉCNICAS ABNT. NBR 11578: Portland composite cement - specification. Rio de Janeiro: ABNT, 1991. 5 p.

[16] ASSOCIAÇÃO BRASILEIRA DE NORMAS TÉCNICAS ABNT. NBR 5738: concrete - procedure for molding and curing concrete test specimens. Rio de Janeiro: ABNT, 2015. 9 p. 
[17] ASSOCIAÇÃO BRASILEIRA DE NORMAS TÉCNICAS ABNT. NBR NM 67: concrete - slump test for determination of the consistency. Rio de Janeiro: ABNT, 1998. 8 p.

[18] ASSOCIAÇÃO BRASILEIRA DE NORMAS TÉCNICAS ABNT. NBR 5739: concrete - compression test of cylindric specimens - method of test. Rio de Janeiro: ABNT, 2007. 9 p.

[19] Réunion Internationale des Laboratoires d'Essais et de Recherches sur les Matériaux et les Constructions - RILEM. Recommandation RILEM/CEB/FIP RC 6: essais portant sur l'adhérence des armatures du béton. 2. Essai par traction. [s.I.]: [s.n.], 1978. 5 p.

[20] SOUDAIS, P. R. N. Estudo da aderência entre o concreto celular e as barras de aço. 2014. 312 f. Dissertação (Mestrado), Universidade Estadual Paulista "Júlio de Mesquita Filho" (UNESP) - Faculdade de Engenharia de Ilha Solteira, Ilha Solteira-SP, 2014. 